\title{
Comparative analysis of normative provisions for seismic design and detailing of reinforced concrete structures
}

\section{Análise comparativa das considerações normativas para dimensionamento e detalhamento sísmico de estruturas de concreto armado}

\author{
R. A. RODRIGUES \\ rrodrigues@usp.br \\ https://orcid.org/0000-0002-7520-6367 \\ C. E. N. MAZZILLI a \\ cenmazzi@usp.br \\ https://orcid.org/0000-0003-0766-2317 \\ T. N. BITTENCOURT a \\ tbitten@usp.br \\ https://orcid.org/0000-0001-6523-2687
}

\begin{abstract}
The main objective of this work is to carry out a comparative analysis between the methods and provisions of the Brazilian code ABNT NBR 15421:2006 and those of the ASCE/SEI 7 and the Eurocode 8, on the seismic design of structures. The similarities and differences between these standards, as far as the application of the Equivalent Lateral Forces method (ELFM) and the Response Spectrum method (RSM) are concerned, will be addressed. The responses will be evaluated for a case study that will be modelled by the SCIA Engineer 17 software. This paper also presents some comments on the detailing of reinforced concrete structures to ensure a good performance under seismic loading, allowing for a more favourable interpretation of the seismic analysis results.
\end{abstract}

Keywords: seismic analysis, response spectrum, ABNT NBR 15421:2006, Eurocode 8, ASCE/SEI 7.

\section{Resumo}

O objetivo principal deste trabalho é fazer uma análise comparativa entre os métodos e considerações da norma brasileira ABNT NBR 15421:2006 e as provisões do ASCE/SEI 7 e do Eurocódigo 8, quanto ao dimensionamento sísmico de estruturas. São verificadas as similaridades e as diferenças entre as instruções normativas, quanto à aplicação do Método das Forças Equivalentes (MFE) e do Espectro de Resposta (MER). Os resultados serão avaliados por meio de um estudo de caso que será processado com auxílio do programa computacional SCIA Engineer 17. O artigo também apresenta alguns comentários sobre o detalhamento de estruturas de concreto armado que visam a garantir um bom desempenho sísmico, possibilitando uma interpretação mais favorável dos resultados sísmicos analisados.

Palavras-chave: análise sísmica, espectro de resposta, ABNT NBR 15421:2006, Eurocódigo 8, ASCE/SEI 7.

Universidade de São Paulo, Escola Politécnica, São Paulo, SP, Brasil.

Received:12 May 2018 • Accepted: 29 Dec 2018 • Available Online:

This is an open-access article distributed under the terms of the Creative Commons Attribution License 


\section{Introduction}

South America is a region with very heterogeneous degrees of seismicity. The eastern border is inserted in an internal tectonic plate, which guarantees greater stability and consequent reduction in the influence of the seismic activities. On the other hand, the western border has a large seismic activity, for it is located on two plate boundaries. This formation, to a certain extent, justifies the fact that the countries located in the western region of South America have already had norms for seismic design for some decades, while in Brazil, the approval of the ABNT NBR 15421: 2006 [1], that defines the procedures for designing buildings in seismic regions, happened only in 2006.

As it can be seen from Figure 1, the influence of seismic events in Brazil, North America and Europe are considerably different, a fact that is very evident in the assumptions of the seismic standards of each of those regions. Nevertheless, there are many similar considerations that will be explored ahead.

The Brazilian standard presents a mapping of seismic accelerations in the country quite compatible with the study presented in Figure 1, which leads to the understanding that the risk of dramatic seismic damages in Brazil is almost zero. However, more recent studies developed by the University of São Paulo, available at http://jornal.usp.br/tv-usp/usp-atualiza-mapa-de-risco-de-tremoresde-terra-no-brasil/, warn for the need to update this mapping. The NBR exempts seismic analysis for areas with design seismic accelerations of less than $0.025 \mathrm{~g}$ and requires a fairly simple verification for accelerations between $0.025 \mathrm{~g}$ and $0.050 \mathrm{~g}$, while the Eurocode 8 [2] allows for no verification for design accelerations smaller than $0.050 \mathrm{~g}$. The American ASCE / SEI 7 [3] standard, unlike the others, uses a response spectrum mapping of accelerations and importance categories to define risk categories for structures, which are defined from "A" to " $F$ ", and then exempts seismic analysis for the first defined category $(A)$.
Section 2 presents in general terms the objectives and criteria adopted by the three standards. Considering the great difference in the occurrence and magnitude of the seismic events in Brazil, Europe and the United States, it should be expected that in the international standards there would have, as indeed they have, a considerably greater amount of information, limitations and instructions for the considerations to be made. In this article, the assumptions of the three standards will be presented, so that they can be compared.

Section 3 shows a comparative study between the parameters adopted by ABNT NBR 15421: 2006 [1], ASCE / SEI [3] and Eurocode 8 [2] for the EFM. Similar to section 3, section 4 presents a comparative study between the parameters adopted by the three standards for the RSM.

Then, in section 5 , a case study is analyzed by both, the EFM and the RSM, resorting to SCIA Engineer 17 software [4] and using the parameters of each of the three standards. Two situations are considered, one based on rocky terrain and the other on less rigid ground, which allows to illustrate and identify the differences between the results obtained by each method, as well as the variations between the provisions of each standard.

In section 6 some comments are presented regarding the structural detailing that aim at guaranteeing a better seismic performance for the reinforced concrete structures, allowing them to fit into a more favorable design hypothesis.

\section{General concept}

The objective of ABNT NBR 15421: 2006 [1], ASCE / SEI [3] and EUROCODE 8 [2] is complementary to other reference standards, with regard to the safety requirements of structures in civil construction, when subjected to seismic actions, aiming at preserving human life, reducing the expected damages and guaranteeing that critical buildings remain operational during and after a seismic event. However, NBR only covers the usual structures, built in a conventional way,

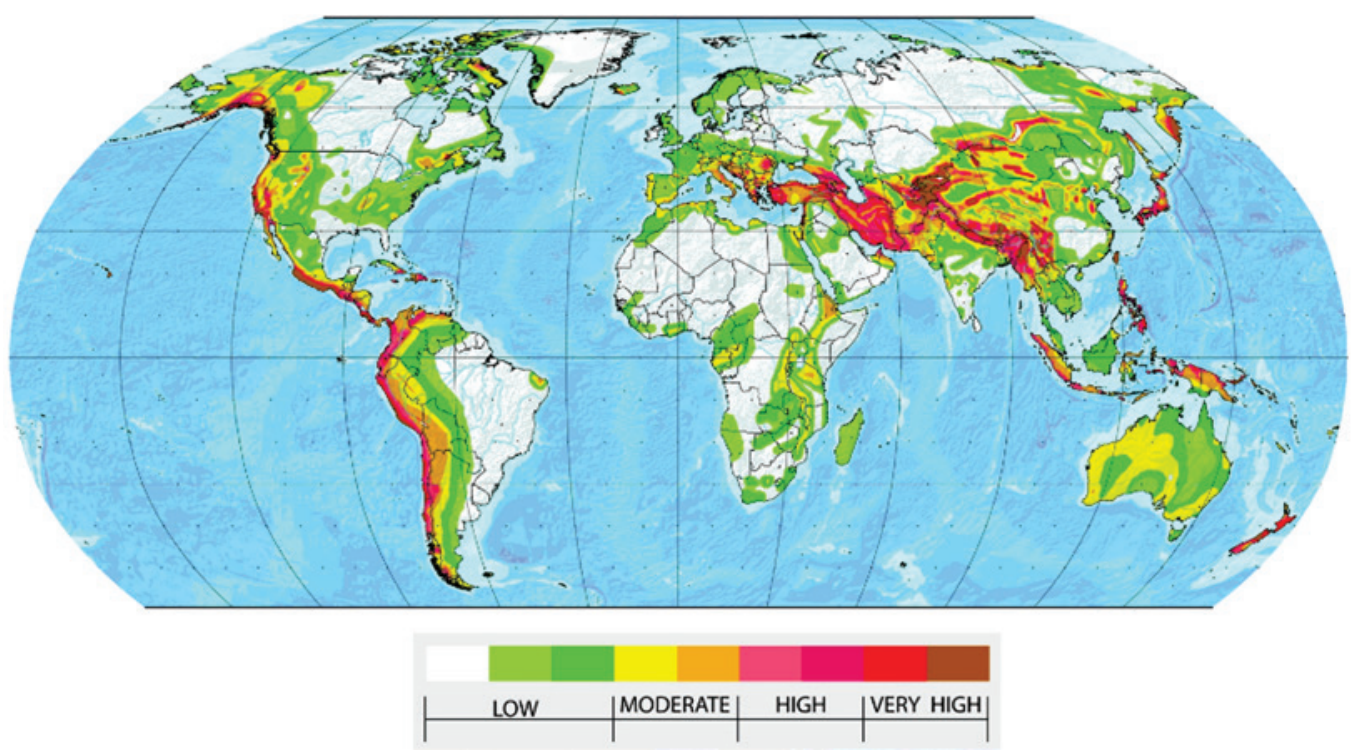

Figure 1

Characteristic horizontal seismic acceleration mapping in the world 
Table 1

Importance coefficient

\begin{tabular}{|c|c|c|c|c|c|c|}
\hline \multicolumn{3}{|c|}{ Category } & \multirow{2}{*}{ Nature of occupation } & \multirow{2}{*}{$\begin{array}{c}1 \\
\text { (NBR) }\end{array}$} & \multirow{2}{*}{$\begin{array}{c}\mathrm{I} \\
\text { (ASCE) } \\
\end{array}$} & \multirow{2}{*}{$\begin{array}{c}\text { I } \\
\text { (EUROCODE }\end{array}$} \\
\hline NBR & ASCE & EUROCODE & & & & \\
\hline- & 1 & 1 & $\begin{array}{l}\text { Minor importance building } \\
\text { (Agricultural) }\end{array}$ & - & 1 & 0.65 \\
\hline I & ॥ & $\|$ & Common buildings & 1 & 1 & 1 \\
\hline$\|$ & III & III & Relevant buildings (schools, etc.) & 1.25 & 1.25 & 1.45 \\
\hline III & IV & IV & $\begin{array}{c}\text { Essential buildings (hospitals, } \\
\text { headquarters, etc.) }\end{array}$ & 1.5 & 1.5 & 1.95 \\
\hline
\end{tabular}

while EUROCODE and ASCE make provisions that are valid for a broader class of constructions, with specific provisions for bridges, viaducts, silos, chimneys, etc. Yet, none of these standards covers the special structures of nuclear power plants, offshore structures and large dams. In this article, the concepts related to reinforced concrete buildings will be primarily addressed.

Regarding the probabilistic considerations of seismic loads, the Brazilian and European standards consider a return period of 475 years (equivalent to a $10 \%$ probability of the project earthquake being exceeded in 50 years) for the ultimate limit state and excessive displacements. Additionally, the European standard requires a further analysis regarding damage control, adopting, in this case, a return period of 95 years. The US standard refers to an application, found at http://earthquake.usgs.gov/designmaps [6], where the seismic parameters for calibrating the spectrum are available, which in turn adopts a return period of 2475 years, based on a $2 \%$ probability of exceeding the project earthquake in 50 years.

The three standards work with the so-called importance coefficient in order to classify the risk and potential damage of the analyzed structures. The importance categories adopted are very similar, however, EUROCODE admits two different sets of coefficients, due to the existence of more than one type of seismic origin in the European region. In this study, it will be considered the set of parameters adopted for what, in EUROCODE 8 [2], is named as "Type 1", because this is the one with the set of parameters that most resembles those considered in the other standards. Table 1 presents the comparison between the aforementioned importance coefficients.

It is not plausible to consider that the structures perform in the elastic regime during a seismic event, therefore, the standards con- sider response-modification coefficients (reduction of efforts and increase of displacements), which takes into account the nonlinear regime of each structural system. Table 2 shows the coefficients adopted for some of the main conventional structural systems. The coefficients $\alpha_{u} / \alpha_{1}$ are defined in item 6.3.1 of EUROCODE 8 [2], depending on the specific type of the analyzed structure (number of floors, number of frames in plan, bracing, etc.), while the superior limit value of the coefficient is given according to item 6.3.2. It is worth mentioning that international standards indicate a much larger number of structural systems, with a much more detailed description, allowing to select the modification coefficients in a much more precise manner.

Once the seismic forces have been determined, the combination suggested in the standards, which considers simultaneously the dynamic and static actions, can be implemented in order to obtain the structural design forces.

The design methodology of the standards addressed in this article is the so-called Force-Based Design (FBD). Although the trend of some contemporary proposals for designing earthquake resistant structures is to use different methodologies-such as the Performance-Based Design (PBD), which establishes target-displacements defined by a pre-established performance level, these standards have not yet incorporated them with due autonomy. This is, in fact, typical of technical standards in Engineering: between the proposals for the state-of-the-art improvement and its effective incorporation into the text of the standards, there is a great temporal lapse due to the necessary and gradual cultural change that must take place not only in the technical environment, as well as in the productive sector. By the way, as explained by Carvalho in

\section{Table 2}

Response-modification factor

\begin{tabular}{cccc}
\hline $\begin{array}{c}\text { Structural systems } \\
\text { (frames) }\end{array}$ & $\begin{array}{c}\text { Modification factor } \\
(\mathbf{R})\end{array}$ & $\begin{array}{c}\text { NBR / ASCE } \\
\text { Displacement amplification } \\
\left(\mathbf{C}_{\mathrm{d}}\right)\end{array}$ & $\begin{array}{c}\text { Modification factor and } \\
\text { displacement amplification } \\
(\mathbf{q})\end{array}$ \\
\hline $\begin{array}{c}\text { Concrete frame - usual } \\
\text { Concrete frame - special }\end{array}$ & 3 & 2.5 & $3.0 \alpha_{\mathrm{u}} / \alpha_{1}$ \\
Moment-resistant & 8 & 5.5 & $4.5 \alpha_{\mathrm{u}} / \alpha_{1}$ \\
steel frame- usual & 3.5 & 3 & $3.0 \alpha_{\mathrm{u}} / \alpha_{1}$ \\
Moment-resistant & 8 & 5.5 & $4.5 \alpha_{\mathrm{u}} / \alpha_{1}$ \\
steel frame- special & 3.25 & 3.25 & $3.0 \alpha_{\mathrm{u}} / \alpha_{1}$ \\
Braced steel frame- usual & 6 & 5 & $4.5 \alpha_{\mathrm{u}} / \alpha_{1}$ \\
Braced steel frame - special & & & \\
\hline
\end{tabular}


Table 3

Ground classification

\begin{tabular}{|c|c|c|c|c|}
\hline \multirow{2}{*}{ Ground class } & $\mathrm{V}_{\mathrm{s}}$ (NBR / ASCE) & NSPT (NBR / ASCE) & $\mathrm{V}_{\mathrm{s}}$ (EUROCODE) & NSPT (EUROCODE) \\
\hline & $\mathrm{m} / \mathrm{s}$ & number & $\mathrm{m} / \mathrm{s}$ & number \\
\hline A & $V_{s}>1500$ & - & $\mathrm{V}_{\mathrm{s}}>800$ & - \\
\hline B & $1500>V_{s}>760$ & - & $800>V_{s}>360$ & $N>50$ \\
\hline $\mathrm{C}$ & $760>V_{s}>370$ & $N>50$ & $360>V_{s}>180$ & $50>N>15$ \\
\hline $\mathrm{D}$ & $370>V_{s}>180$ & $50>N>15$ & $V_{s}<180$ & $N<15$ \\
\hline E & $V_{s}<180$ & $N<15$ & \multirow{2}{*}{\multicolumn{2}{|c|}{ Specific evaluation }} \\
\hline$F(S 1 E S 2)$ & \multicolumn{2}{|c|}{ Specific evaluation } & & \\
\hline
\end{tabular}

[2], with reference to EUROCODE 8, “... the use of force-based design is well established and, as mentioned above, is adopted in EN 1998-1 as the reference method, because most of other actions with which structural designers have to cope are forces imposed to the structures. Hence within the overall design process the use of a force-based approach, even for seismic actions, is very practi$\mathrm{cal}$ and attractive. Furthermore, analytical methods for a displacement-based approach in seismic design are not fully developed and not familiar to the ordinary designer". Only in an alternative way, EUROCODE 8 opens the possibility of a non-linear analysis (pushover) according to the "displacement-approach". In addition, although the PBD is mentioned in item 1.3.1.3 of the American Standard ASCE / SEI 7 (2016), the text itself requires that the results obtained be backed up by analyzes made by the force-based approach. Therefore, PBD will not be addressed in this study.

According to Arai [5], the three norms mention the basic principles of an earthquake-resistant project, in which one must seek structural simplicity, uniformity, plant and elevation regularity, bi-directional stiffness, torsional stiffness, diaphragm behavior on various floors and proper foundation.

The Brazilian standard ABNT NBR 15421: 2006 [1] cites five types of geometric irregularities, which are classified as three in the horizontal plane: 1) torsional, 2) discontinuity in force trajectory in the horizontal plane and 3) elements that support the horizontal plane (columns and walls) not parallel to the vertical axis of the structural system; and two vertical geometric irregularities: (4) discontinuity in the vertical stress path; and (5) characterization of a "weak pavement", which has a lateral resistance of less than $65 \%$ of the immediately-higher-pavement strength. Generally, the Brazilian standard requires the use of a spatial model when there are irregularities in the plane. For structures with vertical irregularities, the NBR calls for the application of a coefficient called "over-resistance", which acts by increasing the seismic forces on the structure, ensuring that its design generates a structure with a higher resistance. The American ASCE / SEI 7 [3] explores in much more detail possible geometric irregularities in the structures, carefully defining the situations and conditions in which the "over-resistance" coefficients must be applied, among other limitations. Similarly, EUROCODE deals with irregularities in the plan requiring the use of a spatial model and vertical irregularities by reducing the response modification coefficient, which is conceptually equivalent to the use of the over-resistance coefficient adopted in NBR and ASCE.

Regarding the methods of analysis, the use of RSM or a timedomain analysis for any structural system is allowed in ASCE / SEI
7 [3]. EFM is allowed for all structures in categories B and C and for categories $D, E$ and $F$ when they are:

i. Risk category I or II, up to two floors;

ii. Light frame constructions;

iii. Structures with no geometric irregularities, with fundamental period < 3.5 Ts (where Ts is defined by equation (10));

iv. Structures up to $50 \mathrm{~m}$ high, with limitations in geometric irregularities.

It is worth noting that the NBR defines the main method as the EFM, while the EUROCODE defines the RSM as the base method. In addition, EUROCODE advises against the use of EFM when there are vertical irregularities, a consideration that is not made in the NBR.

As for the land classes definitions, the three standards take into account the propagation velocity of the secondary waves $\left(V_{s}\right)$ and the number of blows in the SPT test. EUROCODE gives a much more detailed description of the type of soil formation for each class, however the parameters used in the classification are quite similar. Although the land classes defined in the NBR and the ASCE are identical, the American standard requires the submission of a detailed geotechnical report for categories C, D, E or F, including foundation recommendations to mitigate the risk analysis. Table 3 presents the comparison of the terrain classification.

In EUROCODE 8 [2], as well as in ASCE 7 [3], the elastic spectrum for horizontal earthquake is defined from three control periods and three stages: constant acceleration, constant velocity and constant displacement. Similar to the provisions of ABNT NBR 15421: 2006 [1], the other standards allow a nominal structural damping rate of $5 \%$; however, EUROCODE considers a parameter that allows adjusting the spectrum for situations with different damping rates, other than $5 \%$. It should be noted that the structural damping ratio adopted in a seismic analysis is higher than the $2 \%$ value usually used for dynamic analysis of reinforced concrete structures in the elastic regime, since, in a seismic situation, the structures are considered to perform in the elastoplastic regime, and as so, the equivalent structural damping must take into account dissipative inelastic effects. This is done, in a practical way, with an increase in the damping ratio. The NBR basically adopts the same assumptions of the old American UBC standard [7]. Thus, the constant displacement stage is not characterized.

Figure 2 illustrates the spectrum of the analyzed standards, as a function of the parameters that defines them. The parameters for each standard are explained in detail ahead, with the expressions that define the graph curves.

The following expressions define the design spectrum in ABNT NBR 15421: 2006 [1]: 


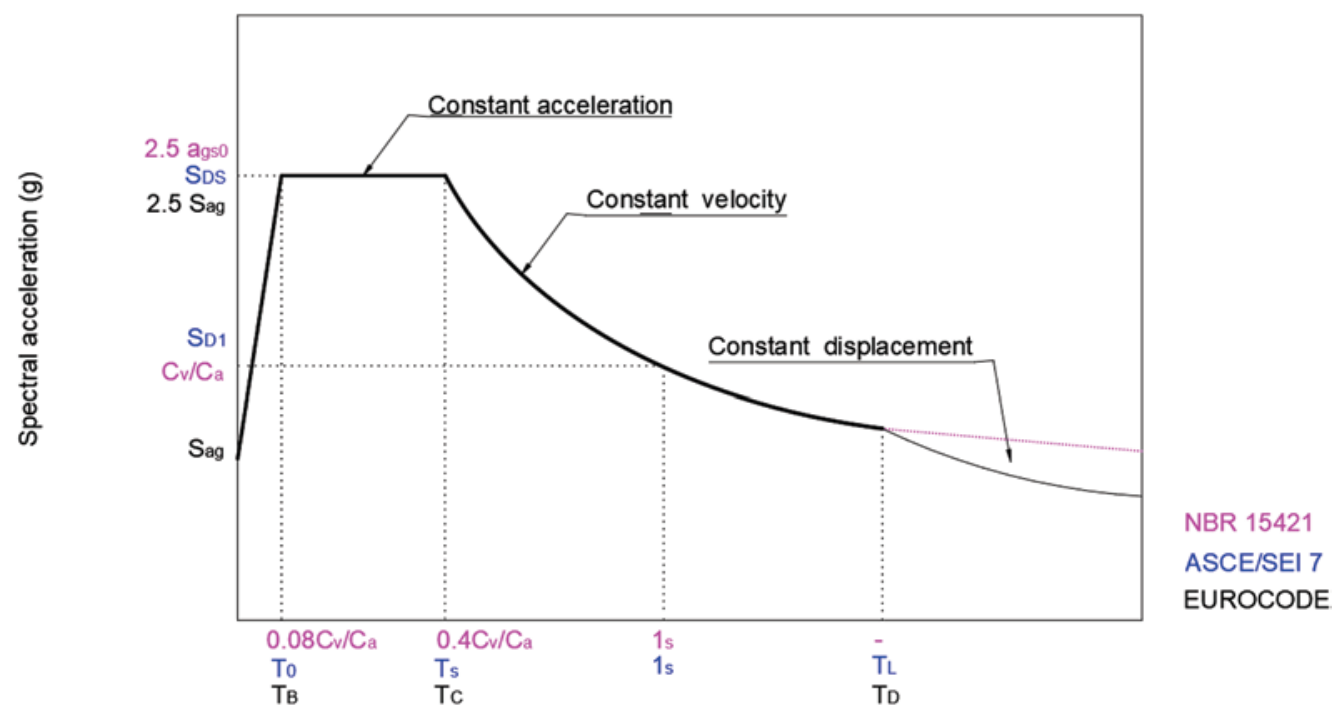

Period, T (s)

Figure 2

Elastic response spectrum, adapted from Eurocode 8 [2]

for $0 \leq T \leq 0.08 \frac{C_{v}}{C_{a}} \quad S_{a}(T)=a_{g s 0} \times\left(18.75 \times T \times \frac{C_{v}}{C_{a}}+1.0\right)$

for $0.08 \frac{C_{v}}{C_{a}} \leq T \leq 0.4 \frac{C_{v}}{C_{a}} \quad S_{a}(T)=a_{g s 0} \times 2.5$

for $T \geq 0.4 \frac{C_{v}}{C_{a}} \quad S_{a}(T)=\frac{a_{g s 1}}{T}$

where:

$\mathrm{a}_{\mathrm{gs} 0}=\mathrm{C}_{\mathrm{a}} \times \mathrm{a}_{\mathrm{g}}$

$\mathrm{a}_{\mathrm{gs} 1}=\mathrm{C}_{\mathrm{v}} \times \mathrm{a}_{\mathrm{g}}$

The parameters $\mathrm{a}_{\mathrm{gs} 0}$ and $\mathrm{a}_{\mathrm{gs} 1}$ are the spectral accelerations for a period of zero and one seconds, respectively, obtained as a function of the design characteristic acceleration $\mathrm{a}_{\mathrm{g}}$. The parameters $\mathrm{C}_{\mathrm{a}}$ and $\mathrm{C}_{\mathrm{v}}$ (amplification factors in soil for the respective periods of zero and one seconds) are defined in Table 3 of ABNT NBR 15421: 2006 [1], according to the land class and the characteristic acceleration defined by the seismic zone where the structure is located. The natural period "T" is the period of each mode of vibration of the analyzed structure, in seconds.

ASCE / SEI 7 [3] defines the maximum considered earthquake (MCE) - through the parameters:

$S_{m s}=F_{a} \times S_{s}$

$S_{m 1}=F_{v} \times S_{1}$

where:

$F_{a}$ and $F_{v}$ are the weighting coefficients in soil, defined in Tables 11.4-1 and 11.4-2 of ASCE/SEI 7 [3], which are presented in Table $5 ; S_{s}$ and $S_{1}$ are the spectral acceleration response parameters for the periods of 0.2 and one seconds, respectively, which after being adjusted by the weighting coefficients in the soil, give rise to the parameters $S_{m s}$ and $S_{m 1}$. The $S_{s}$ and $S_{1}$ parameters are provided by the detailed maps, which can be found at http://earthquake.usgs.gov/designmaps.

For the characterization of the design spectrum, the parameters $\mathrm{S}_{\mathrm{DS}}$ and $\mathrm{S}_{\mathrm{D} 1}$ are defined, respectively, by $\frac{2}{3} \times S_{m s}$ and $\frac{2}{3} \times S_{m 1}$, presented in the equation (4).
The following expressions define the design spectrum in ASCE:

for $T<T_{0} \quad S_{a}(T)=S_{D S}\left(0.4+0.6 \frac{T}{T_{0}}\right)$

for $T_{0} \leq T \leq T_{S} \quad S_{a}(T)=S_{D S}$

for $T_{S} \leq T \leq T_{L} \quad S_{a}(T)=\frac{S_{D 1}}{T}$

for $T \geq T_{L} \quad S_{a}(T)=\frac{S_{D 1} \times T_{L}}{T^{2}}$

where:

$\mathrm{S}_{\mathrm{a}}$ is the spectral acceleration for each defined period $\mathrm{T}$ (in $\mathrm{s}$ ).

$T_{0}=0.2 \times \frac{S_{D 1}}{S_{D S}}$

$T_{S}=\frac{S_{D 1}}{S_{D S}}$

$\mathrm{T}_{1}=$ transition period shown in figures $22-12$ to $22-16$ of ASCE/ SEI 7 [3].

Considering that Europe is a region with more than one seismic origin, EUROCODE defines two typical design spectra, according to Arai [5]: Type 1 for regions of magnitudes greater than 5.5 and Type 2 for regions smaller than 5.5.

The spectrum is then defined by the following expressions:

for $0 \leq T \leq T_{B} \quad S_{a, d}(T)=a_{g} \times S \times\left(\frac{2}{3}+\frac{T}{T_{B}} \times\left(\frac{2.5}{q}-\frac{2}{3}\right)\right.$

for $T_{B} \leq T \leq T_{C} \quad S_{a, d}(T)=a_{g} \times S \times \frac{2.5}{q}$

for $T_{C} \leq T \leq T_{D} \quad S_{a, d}(T)=a_{g} \times S \times \frac{2.5}{q} \times \frac{T_{C}}{T} \geq 0.2 a_{g}$

for $T \geq T_{D} \quad S_{a, d}(T)=a_{g} \times S \times \frac{2.5}{q} \times \frac{T_{C} \times T_{D}}{T^{2}} \geq 0.2 a_{g}$

in which:

$\mathrm{S}_{\mathrm{a}, \mathrm{d}}$ is the ordinate referring to the adopted design acceleration spectrum; 
$\mathrm{S}, \mathrm{T}_{\mathrm{B}}, \mathrm{T}_{\mathrm{C}}$ and $\mathrm{T}_{\mathrm{D}}$ are defined in Tables 3.2 and 3.3 of Eurocode 8 [2] and presented at Table 4;

$a_{\mathrm{g}}$ is the surface design acceleration, derived from the characteristic acceleration $\mathrm{a}_{\mathrm{gr}}$, defined by the seismic zone available in each country's National Annex.

The NBR and the ASCE assume that the responses obtained by the response spectrum should be adjusted by the response-modification factors shown in Table 2. The Eurocode takes into account the response-modification factor (q) already embedded in the expressions (11) to (14). Therefore, the spectrum already provides the compatibilized results.

\section{Equivalent lateral forces method}

ABNT NBR 15421: 2006 [1] adopts the Equivalent Lateral Forces Method (EFM) as the main analysis procedure and allows its use for all structures to which the standard refers. EUROCODE 8 [2], however, limits its use to structures that are uniform in elevation and have fundamental periods of less than $4 \times \mathrm{T}_{\mathrm{C}}$ or $2 \mathrm{~s}$.

The Brazilian standard defines EFM by the following expressions, based on the parameters of the response spectrum and the impor-

\section{Table 4}

Design spectrum parameters tance and response-modification coefficients, defined in section 2 (valid for each direction analyzed):

horizontal force at the base:

$H=C_{s} \times W$

$\mathrm{C}_{\mathrm{s}}$ is the coefficient of seismic response, given by:

$C_{s}=\frac{2.5 \times \frac{a_{g s 0}}{g}}{\frac{R}{I}}$ limited to $0.01<C_{s}<\frac{2.5 \times \frac{a_{g s 1}}{g}}{T \times \frac{R}{I}}$

The parameters used are those defined in section 2 , where $\mathrm{W}$ is the total weight of the structure and $T$ is the fundamental vibration period of the structure in seconds, relative to the first mode of vibration in the direction analyzed, or by the simplification that follows:

$T=C_{t} \times h^{z}$

where $\mathrm{h}$ is the height of the structure in meters above the base, with the parameters " $C_{t}$ " and " $z$ " defined at Table 5.

The total horizontal force at the base $(\mathrm{H})$ is distributed vertically, between the various elevations " $x$ " of the structure, according to the expression below:

$F_{x}=C_{v x} \times H$

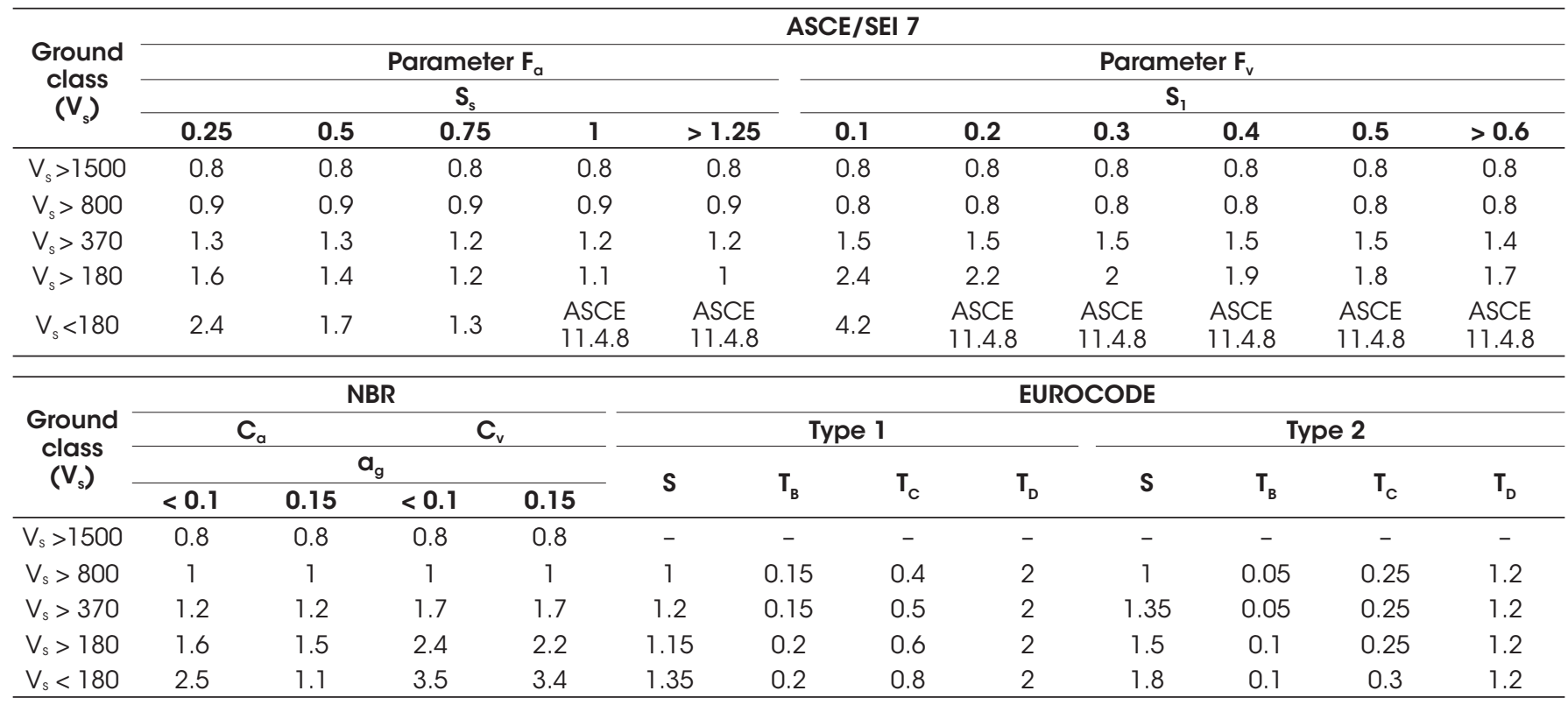

Table 5

Coefficients " $\mathrm{C}_{\dagger}$ " and " $\mathrm{z}$ "

\begin{tabular}{|c|c|c|c|c|}
\hline \multirow{2}{*}{ Structure type } & \multicolumn{2}{|c|}{ NBR / ASCE } & \multicolumn{2}{|c|}{ EUROCODE } \\
\hline & $C_{t}$ & $\mathbf{z}$ & $\mathrm{C}_{\mathrm{f}}$ & $\mathbf{z}$ \\
\hline Moment resistant steel frame & 0.0724 & 0.8 & 0.085 & 0.75 \\
\hline Concrete frame & 0.0466 & 0.9 & 0.075 & 0.75 \\
\hline Braced steel frame & 0.0731 & 0.75 & 0.075 & 0.75 \\
\hline Other structures & 0.0488 & 0.75 & 0.05 & 0.75 \\
\hline
\end{tabular}


where the coefficient $C_{v x}$ considers the weight and height " $x$ " in relation to the base, for the floor to be loaded.

$C_{v x}=\frac{W_{x} h_{x}^{k}}{\sum_{i=1}^{n} W_{i} h_{i}^{k}}$

where $W_{x}$ is the effective weight corresponding to the floor of the analyzed " $\mathrm{x}$ " elevation, $\mathrm{h}_{\mathrm{x}}$ is the distance from the floor in elevation " $\mathrm{x}$ " relative to the base; $W_{i}$ and $h_{i}$ are analogous to $W_{x}$ and $h_{x}$, yet for elevation "i"; and $\mathrm{k}$ is a coefficient relative to the natural period $\mathrm{T}$ (in $\mathrm{s}$ ): $\mathrm{k}=1$ for $\mathrm{T}<0.5 \mathrm{~s}$;

$k=(T+1.5) / 2$ for $0.5 \mathrm{~s}<\mathrm{T}<2.5 \mathrm{~s}$;

$\mathrm{k}=2$ for $\mathrm{T}>2.5 \mathrm{~s}$.

The displacements obtained must be multiplied by the ratio $\frac{C_{d}}{I}$, in which $C_{d}$ is given in Table 2 and the coefficient I in Table 1.

The formulation for EFM presented by ASCE / SEI 7 [3] is essentially the same as the one presented in the NBR, with the following particularities:

1. The seismic response coefficient $C_{s}$, defined as a function of the parameters presented in section 2 , is given by:

$C_{s}=\frac{S_{D S}}{\left(\frac{R}{I}\right)}$ limited to $\frac{S_{D 1}}{T\left(\frac{R}{I}\right)}$ for $\mathrm{T}<T_{L}$, or $\frac{S_{D 1} \times T_{L}}{T^{2}\left(\frac{R}{I}\right)}$ for $\mathrm{T}>\mathrm{T}_{\mathrm{L}}$

where $\mathrm{C}_{\mathrm{s}}$ shall not be less than:

$\frac{0.5 \times S_{1}}{\frac{R}{I}}$ for seismic zones with $S_{1} \geq 0.6 \mathrm{~g}$

$0.044 \times S_{D S} \times I$ for other cases

2. In addition to the simplification of the fundamental period of the structure presented by NBR, for reinforced concrete structures or moment-resistant steel frames with up to 12 floors and at least three meters between each floor, it is possible to estimate the fundamental period $\mathrm{T}(\mathrm{s})$ by:

$T=0.1 \times N$

with $\mathrm{N}=$ number of floors above the base.

In any event, the assumed fundamental period shall not exceed the product of equation (17) by the coefficient $C_{u}$ established in Table 12.8-1 of ASCE / SEI 7 [3].

Eurocode 8 [2] presents a slightly different formulation for the total force in the base which, presented in the notation of this article, is given by:

$H=S_{a, d}(T) \times W \times \lambda$

where $T$ is the fundamental period of the structure in seconds; $S_{a, d}$ is the ordinate referring to the design acceleration spectrum adopted, normalized with respect to the acceleration of gravity; $W$ is the total weight of the structure and $\lambda=0.85$ when $T<T_{c}$ and the building is more than two-floors high; or $\lambda=1.0$ in the other cases. In addition to the estimations for the fundamental period $(T)$ defined in the NBR, Eurocode allows the use of the following expression:

$T=2 \times \sqrt{d}$

with $d$ being the lateral displacement at the top of the building, in meters, referring to the forces of gravity acting in the horizontal direction. For the distribution of seismic forces through the height of the structure, Eurocode considers the following formulation:
$F_{x}=H \times \frac{s_{x} \times m_{x}}{\sum s_{i} \times m_{i}}$

where:

$\mathrm{m}_{\mathrm{x}}=$ floor mass at elevation " $\mathrm{x}$ ";

$m_{i}=$ floor mass at elevation "i".

The parameters $s_{x}$ and $s_{i}$ can be taken with respect to a linear distribution in relation to the height of the building, where:

$\mathrm{S}_{\mathrm{x}}=$ floor height at elevation " $\mathrm{x}$ " with respect to the base;

$\mathrm{s}_{\mathrm{i}}=$ floor height at elevation "i" with respect to the base.

Alternatively, one may adopt these parameters with respect to the displacement of the masses in the fundamental mode of vibration of the structure, where:

$\mathrm{s}_{\mathrm{x}}=$ relative displacement of the floor at elevation " $\mathrm{x}$ ";

$\mathrm{S}_{\mathrm{i}}=$ relative displacement of the floor at elevation " $\mathrm{i}$ ".

The displacements obtained by this method must be multiplied by the displacement amplification coefficient " $q$ ", shown in Table 2.

Among the "advantages" of the equivalent lateral force method it is frequently cited the ease for application in projects and the low computational cost. One should, however, use this method with caution, since, as shown in section 5 , it is based only on the response of the first mode of vibration of the structure; therefore, may not yield good results in cases where higher modes are excited.

\section{Response spectrum method}

The three analyzed standards define that the analysis by response spectrum is done by modal superposition, with a number of modes analyzed so that at least $90 \%$ of the total mass participates in the response. In addition, the standards allow for a modal combination as indicated by the Square Root of the Sum of the Squares (SRSS) method, to be performed whenever the natural frequency of one mode is at least $10 \%$ higher than the frequency of the adjacent mode.

According to the expression 3.7 of Eurocode 8 [2], for natural periods of up to $4 \mathrm{~s}$, the elastic response spectrum of the displacements $\left(\mathrm{S}_{\mathrm{De}}\right)$ can be obtained directly from the elastic acceleration spectrum $\left(\mathrm{S}_{\mathrm{e}}\right)$, defined in the item 3.2.2.2 of the Eurocode 8 [2], by means of the following expression:

$S_{D e}(T)=S_{e}(T) \times\left[\frac{T}{2 \pi}\right]^{2}$

For the European standard, the design spectrum $\left(\mathrm{S}_{\mathrm{a}, \mathrm{d}}\right)$ has the coefficient " $q$ " embedded in the equation, so the obtained stresses are taken with their nominal values, but the displacements obtained by means of $S_{a, d}$ must be multiplied by the parameter "q" to obtain the final displacements. The forces of the spectral analysis obtained by NBR and ASCE should be multiplied by $\frac{I}{R}$, where $\mathrm{I}$ and $\mathrm{R}$ are given respectively in Table 1 and Table 2 . Regarding the displacements, the two standards determine that they must be multiplied by the ratio $\frac{C_{d}}{R}$, where $\mathrm{C}_{\mathrm{d}}$ and $\mathrm{R}$ are given in Table 2.

The Brazilian standard allows RSM to reduce the shear stress in the base by up to $15 \%$ with respect to the EFM. Hence, if the base shear force obtained by the spectral analysis $\left(\mathrm{H}_{\mathrm{s}}\right)$, is less than $85 \%$ of the base shear force obtained by EFM $\left(\mathrm{H}_{\mathrm{f}}\right)$, all the forces obtained by the spectral analysis should be adjusted by multiplying it by the ratio $0,85 \mathrm{H}_{\mathrm{f}} / \mathrm{H}_{\mathrm{s}}$. This correction is not needed for the 
displacements. The American standard does not allow such reductions in relation to the EFM. Therefore, for the above case, both stresses and displacements would have to be multiplied by the coefficient $\mathrm{H}_{\mathrm{f}} / \mathrm{H}_{\mathrm{s}}$. Eurocode does not correct the values obtained through RSM in relation to EFM; therefore, the values obtained from the analysis can be used at once.

\section{Discussions and results}

For general torsion checks, the three standards specify an accidental eccentricity in relation to the center of mass of the building. This accidental eccentricity is estimated as $5 \% \times \mathrm{Li}$, with $\mathrm{Li}$ being the largest linear length in the floor plan, in the direction perpendicular to the seismic action. If an analysis is made considering two orthogonal directions, the accidental eccentricity should only be applied to the one that maximizes the effects, the simultaneous application in both directions being exempted. Thus, the torque applied to each floor is given by the floor lateral force multiplied by the corresponding accidental eccentricity.

To verify the second-order effects, the standards specify a coefficient of stability $\Theta$ given by:

$\theta=\frac{P_{x} \times \Delta_{x}}{H_{x} \times h_{x}}$

where:

$P_{x}=$ service vertical force acting on the floor;

$\Delta_{\mathrm{x}}=$ interstory drift;

$\mathrm{H}_{\mathrm{x}}$ = shear force acting on the pavement;

$\mathrm{h}_{\mathrm{x}}=$ interstory distance.

The three standards state that for $\Theta$ values less than 0.1 , no second order effects need to be considered. For values of $\Theta$ greater than 0.1 but less than the $\Theta_{\max }$ accepted, displacements and stresses will be multiplied by the ratio $\frac{1}{1-\theta}, \Theta_{\max }$ being defined by:

NBR and ASCE: $\theta_{\max }=\frac{0.5}{C d} \leq 0.25$;

Eurocode: $\theta_{\max }=0.2$

\section{CASE STUDY}

In order to comparatively analyze the provisions of the three standards, a three-floor conventional reinforced concrete model building, similar to that used by Lima and Santos [8] was adopted. The 3D model along with the axis directions considered in the analysis are shown in Figure 3. It should be noted that in Figure 3, the elevation coordinate has been defined as " $z$ ", differently from what has been used in equations (18), (19), (25) and (27), in which it has been termed "x".

This building was subdivided into two groups of analysis, in which the first one considers a conventional reinforcement detail (DC) and the other a specific reinforcement earthquake-resistant detail (DS).

The building has columns with a $50 \times 40 \mathrm{~cm}^{2}$ section, beams with an $80 \times 30 \mathrm{~cm}^{2}$ section and slabs of $11 \mathrm{~cm}$ thickness, built with an $\mathrm{f}_{\mathrm{ck}}=30 \mathrm{MPa}$ concrete.

As seismic characteristics, an acceleration zone $a_{\mathrm{g}}=0.10 \mathrm{~g}$ was considered. For the application of the American standard, the city of Saint Louis, Oakville, in the United States was adopted which, according to the Unified Hazard Tool available at http://earthquake.usgs.gov/designmaps, features a characteristic spectral acceleration (PGA) of $0.10 \mathrm{~g}$ for a return period of 475 years, making this location compatible with the seismic characteristics considered for the other two standards. It is worth remembering though, that for the application of this standard's equations, the parameters for a return period of 2475 years, obtained on February 22, 2018 from the same website of the American government, had to be applied.

The analyses were computed for loadings in the parallel direction to the " $x$ " axis, for two types of foundations, one in sand with average SPT N = 30 and another in bedrock with class of terrain "A", as presented in Table 3.

Eurocode provisions were taken for a Type 1 earthquake spectrum.

\subsection{Lateral equivalent force method analysis}

For the model building, the weight of each floor was approximately and uniformly determined as:

Permanent load per floor: $1740 \mathrm{kN}$;

Total permanent load: $3 \times 1740=5220 \mathrm{kN}$.

With the aid of the expressions presented in this study for the three standards, the parameters for the analysis, presented in Table 6 , were obtained.

For the total shear forces at the base $(\mathrm{H})$ obtained in each analysis, the equivalent vertical distributions were computed. Table 7 shows the calculated distribution for DC cases. The same procedure was adopted to obtain the distribution of the DS cases.

With the equivalent lateral forces calculated, an elastic analysis model was generated with the aid of SCIA Engineer 17 [4], from which the displacements and stresses in the structural elements were obtained, which are presented in Table 9 and in Table 10.

\subsection{Response spectrum analysis}

For the response spectrum analysis, the same base parameters presented in the previous subsection were used to generate the acceleration spectra and, consequently, the displacement spectra.

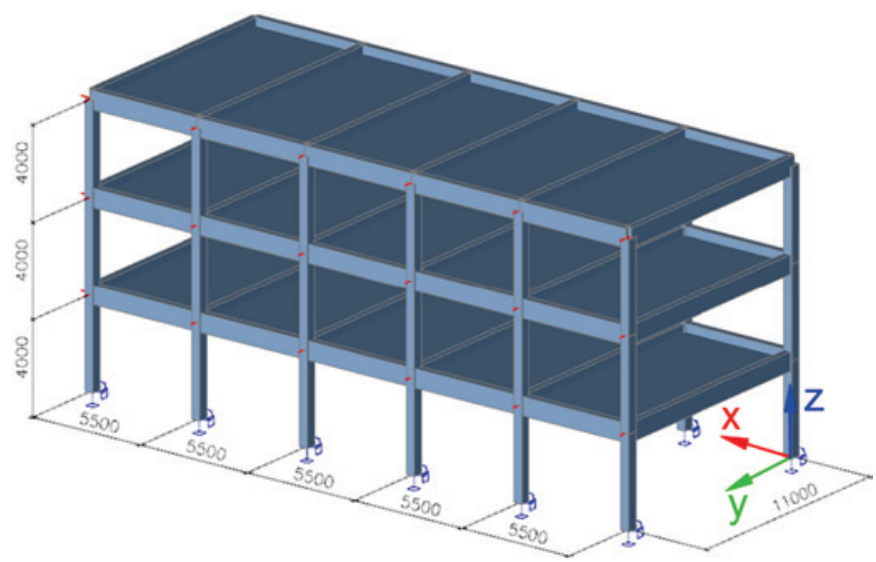

Figure 3

Reference building

Source: author 
Table 6

Reference building parameters

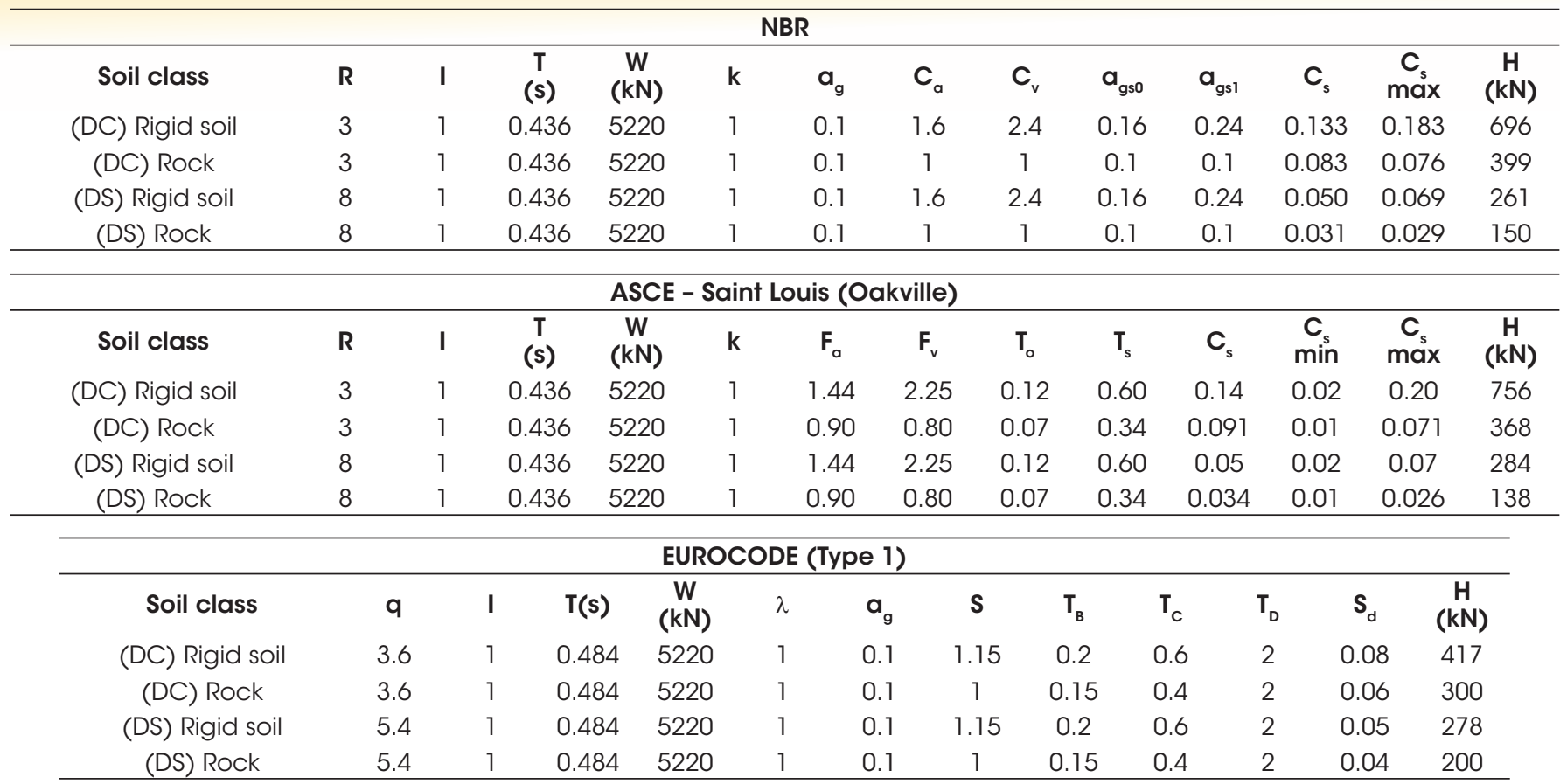

These spectra were inserted in SCIA Engineer 17 [4], from which the displacements and the stresses for the comparative analysis were obtained.

Figure 4 compares the spectra generated by each standard for each of to the two foundation types assumed.

Ten modes of vibration were considered to perform the spectral analysis. Table 8 , which presents the first six modes of the analyzed model, shows that the use of only three modes would be enough to reach $90 \%$ of mass translation in the analyzed direction $(\mathrm{x})$, nonetheless, the software's standard was used.

\subsection{Results}

The comparative results of the analysis performed for the model building, through SCIA Engineer, are presented below, already considering the adjustments made by the response-modification coefficients ("R" and "q"), as well as the displacements coefficients (" $\mathrm{C}_{\mathrm{d}}$ " and "q").

The values presented in Table 9 and Table 10 do not consider the forces and displacements compatibility for the RSM in relation to the EFM yet, as suggested in section 4. After this compatibilization has been carried out, the RSM responses are adjusted to the values presented in Table 11.

In this case study, when considering a conventional reinforcement

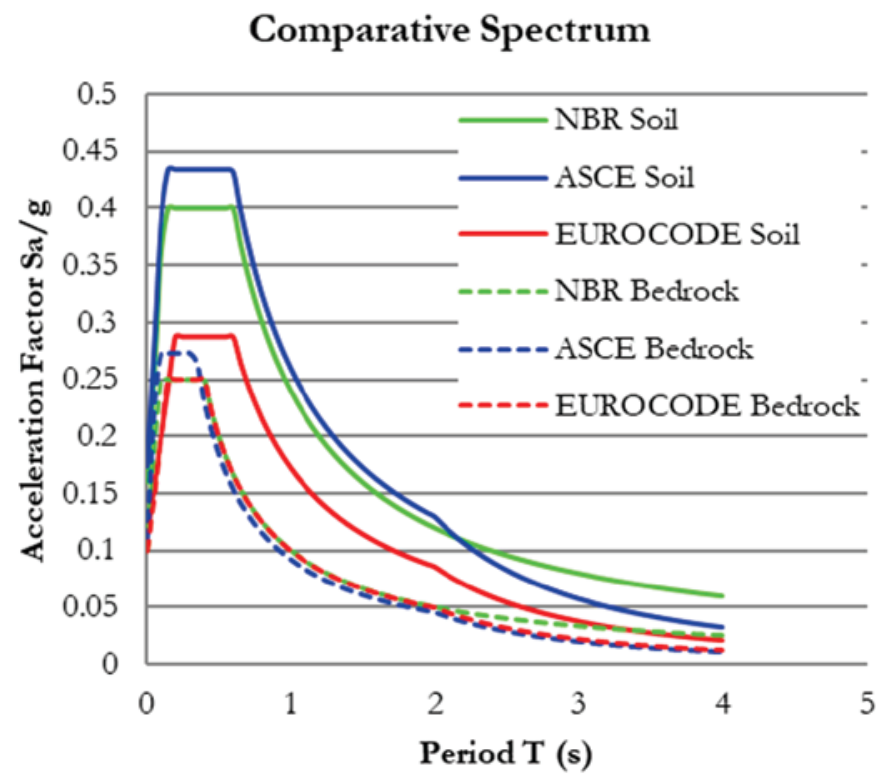

Figure 4

Spectra comparison

Source: author

\section{Table 7}

Distributed forces (rigid soil - DC)

\begin{tabular}{|c|c|c|c|c|c|c|c|c|c|}
\hline & \multirow{2}{*}{ Floor } & \multirow{2}{*}{$\begin{array}{l}h_{x} \\
(m)\end{array}$} & \multirow{2}{*}{$\begin{array}{c}\mathrm{w}_{\mathrm{x}} \\
(\mathrm{kN})\end{array}$} & \multicolumn{2}{|c|}{ NBR } & \multicolumn{2}{|c|}{ ASCE } & \multicolumn{2}{|c|}{ EUROCODE } \\
\hline & & & & $F_{x}(k N)$ & $\mathrm{H}_{\mathrm{x}}(\mathrm{kN})$ & $F_{x}(k N)$ & $\mathrm{H}_{\mathrm{x}}(\mathrm{kN})$ & $F_{\mathrm{x}}(\mathrm{kN})$ & $H_{x}(k N)$ \\
\hline \multirow{3}{*}{$\begin{array}{c}\text { Rigid } \\
\text { soil }\end{array}$} & 3 & 12 & 1740 & 348 & 348 & 378 & 378 & 208 & 208 \\
\hline & 2 & 8 & 1740 & 232 & 580 & 252 & 630 & 139 & 347 \\
\hline & 1 & 4 & 1740 & 116 & 696 & 126 & 756 & 69 & 417 \\
\hline \multirow{3}{*}{ Rock } & 3 & 12 & 1740 & 200 & 200 & 184 & 184 & 150 & 150 \\
\hline & 2 & 8 & 1740 & 133 & 333 & 123 & 307 & 100 & 250 \\
\hline & 1 & 4 & 1740 & 67 & 399 & 61 & 368 & 50 & 300 \\
\hline
\end{tabular}


detail, one can perceive that the force-weighting coefficients, suggested by Eurocode, are more favorable than those presented by the NBR, in addition to the European spectrum being much milder. These aspects, in the analyzed case, lead to considerably smaller shear forces according to the European standard than those obtained by an equivalent analysis according to NBR. The American standard, on the other hand, has weighting coefficients similar to those of the NBR, but uses a slightly heavier response spectrum. Nevertheless, in compliance with the limitations of " $\mathrm{C}_{\mathrm{s}}$ " imposed by the ASCE, presented in equations (20) and (21), which make the responses slightly different from those of a direct application of the American standard spectrum, the results are quite close to those obtained by NBR for the EFM. However, with respect to RSM, the deviations between NBR and ASCE are much more pronounced, due to the American standard requirement that the RSM results be "scaled" to $100 \%$ of the shear base force obtained by the EFM. For the specific earthquake-resistant reinforcement detail shown in this example, the deviations between the NBR and the ASCE are very similar to those obtained for a conventional detailing. However, the deviations obtained with respect to the Eurocode acquire a very different proportion, since the relationships between the weighting coefficients for each type of detail are significantly different.

Particularly for this study, regardless of the adopted standard, it is very clear that the adoption of an earthquake-resistant detail sub-

Table 8

Modal participation factors

\begin{tabular}{|c|c|c|c|c|c|c|c|c|c|}
\hline \multirow[b]{2}{*}{ Mode } & \multirow[b]{2}{*}{$\begin{array}{c}\text { Circular } \\
\text { frequency }(\omega) \\
{[\mathrm{rad} / \mathrm{s}]}\end{array}$} & \multirow[b]{2}{*}{$\begin{array}{c}\text { Period } \\
\text { [s] }\end{array}$} & \multirow[b]{2}{*}{$\begin{array}{c}\text { Cyclic } \\
\text { frequency } \\
{[\mathrm{Hz}]}\end{array}$} & \multicolumn{6}{|c|}{ Mass share of each mode relative to the total } \\
\hline & & & & $\begin{array}{c}\% \\
\text { translation } \\
\text { axis } x\end{array}$ & $\begin{array}{c}\% \\
\text { translation } \\
\text { axis y }\end{array}$ & $\begin{array}{c}\% \\
\text { translation } \\
\text { axis z }\end{array}$ & $\begin{array}{c}\% \\
\text { rotation } \\
\text { axis } \mathrm{x}\end{array}$ & $\begin{array}{c}\% \\
\text { rotation } \\
\text { axis y }\end{array}$ & $\begin{array}{c}\% \\
\text { rotation } \\
\text { axis z }\end{array}$ \\
\hline 1 & 119.322 & 0.5266 & 18.991 & 0.8815 & 0.0000 & 0.0000 & 0.0000 & 0.1152 & 0.0000 \\
\hline 2 & 322.666 & 0.1947 & 51.354 & 0.0000 & 0.0000 & 0.0000 & 0.0000 & 0.0000 & 0.8464 \\
\hline 3 & 349.009 & 0.1800 & 55.546 & 0.0871 & 0.0000 & 0.0000 & 0.0000 & 0.7666 & 0.0000 \\
\hline 4 & 533.548 & 0.1178 & 84.917 & 0.0162 & 0.0000 & 0.0000 & 0.0000 & 0.0434 & 0.0000 \\
\hline 5 & 983.627 & 0.0639 & 156.549 & 0.0000 & 0.0000 & 0.0000 & 0.0000 & 0.0000 & 0.1022 \\
\hline 6 & 1.570 .494 & 0.0400 & 249.952 & 0.0000 & 0.0000 & 0.0000 & 0.0000 & 0.0000 & 0.0245 \\
\hline \multicolumn{4}{|c|}{ Summation } & 0.9847 & 0.0000 & 0.0000 & 0.0000 & 0.9252 & 0.9730 \\
\hline
\end{tabular}

\section{Table 9}

Analysis results - DC

\begin{tabular}{|c|c|c|c|c|c|c|c|c|c|c|c|c|}
\hline & \multicolumn{2}{|c|}{ NBR EFM } & \multicolumn{2}{|c|}{ NBR RSM } & \multicolumn{2}{|c|}{ ASCE EFM } & \multicolumn{2}{|c|}{ ASCE RSM } & \multicolumn{2}{|c|}{ EUROCODE EFM } & \multicolumn{2}{|c|}{ EUROCODE RSM } \\
\hline & Soil & Rock & Soil & Rock & Soil & Rock & Soil & Rock & Soil & Rock & Soil & Rock \\
\hline $\begin{array}{l}\text { Disp. } \\
(\mathrm{mm})\end{array}$ & 33.50 & 19.25 & 28.50 & 13.50 & 36.50 & 17.75 & 31.00 & 12.50 & 28.80 & 20.88 & 24.48 & 16.20 \\
\hline $\begin{array}{c}\mathrm{H} \text { base } \\
(\mathrm{kN})\end{array}$ & 62 & 36 & 55 & 27 & 67 & 33 & 60 & 25 & 37 & 27 & 33 & 22 \\
\hline \multicolumn{5}{|c|}{ Displacement deviation with respect to NBR } & $9.0 \%$ & $-7.8 \%$ & $8.8 \%$ & $-7.4 \%$ & $-14.0 \%$ & $8.5 \%$ & $-14.1 \%$ & $20.0 \%$ \\
\hline \multicolumn{5}{|c|}{ Shear force deviation with respect to NBR } & $8.6 \%$ & $-7.7 \%$ & $8.8 \%$ & $-7.2 \%$ & $-39.9 \%$ & $-24.7 \%$ & $-39.9 \%$ & $-15.5 \%$ \\
\hline
\end{tabular}

\section{Table 10}

Analysis results - DS

\begin{tabular}{|c|c|c|c|c|c|c|c|c|c|c|c|c|}
\hline & \multicolumn{2}{|c|}{ NBR EFM } & \multicolumn{2}{|c|}{ NBR RSM } & \multicolumn{2}{|c|}{ ASCE EFM } & \multicolumn{2}{|c|}{ ASCE RSM } & \multicolumn{2}{|c|}{ EUROCODE EFM } & \multicolumn{2}{|c|}{ EUROCODE RSM } \\
\hline & Soil & Rock & Soil & Rock & Soil & Rock & Soil & Rock & Soil & Rock & Soil & Rock \\
\hline $\begin{array}{c}\text { Disp. } \\
\text { (mm) }\end{array}$ & 27.50 & 15.95 & 23.65 & 11.55 & 30.25 & 14.85 & 25.85 & 10.45 & 29.16 & 21.06 & 24.84 & 16.20 \\
\hline $\begin{array}{c}\mathrm{H} \text { base } \\
(\mathrm{kN})\end{array}$ & 23 & 15 & 21 & 13 & 25 & 15 & 23 & 13 & 25 & 19 & 22 & 16 \\
\hline \multicolumn{5}{|c|}{ Displacement deviation with respect to NBR } & $10.0 \%$ & $-6.9 \%$ & $9.3 \%$ & $-9.5 \%$ & $6.0 \%$ & $32.0 \%$ & $5.0 \%$ & $40.3 \%$ \\
\hline \multicolumn{5}{|c|}{ Shear force deviation in respect to NBR } & $8.5 \%$ & $-4.1 \%$ & $7.1 \%$ & $-3.5 \%$ & $6.4 \%$ & $20.8 \%$ & $5.3 \%$ & $22.5 \%$ \\
\hline
\end{tabular}

\section{Table 11}

Compatibilized results RSM

\begin{tabular}{|c|c|c|c|c|c|c|c|c|c|c|c|c|}
\hline & \multicolumn{6}{|c|}{ DC } & \multicolumn{6}{|c|}{ DS } \\
\hline & \multicolumn{2}{|c|}{ NBR } & \multicolumn{2}{|c|}{ ASCE } & \multicolumn{2}{|c|}{ EUROCODE } & \multicolumn{2}{|c|}{ NBR } & \multicolumn{2}{|c|}{ ASCE } & \multicolumn{2}{|c|}{ EUROCODE } \\
\hline & Soil & Rock & Soil & Rock & Soil & Rock & Soil & Rock & Soil & Rock & Soil & Rock \\
\hline $\begin{array}{l}\text { Disp. } \\
(\mathrm{mm})\end{array}$ & 28.5 & 13.5 & 34.6 & 16.7 & 24.5 & 16.2 & 23.7 & 11.6 & 28.7 & 12.1 & 24.8 & 16.2 \\
\hline $\begin{array}{l}\mathrm{H} \text { base } \\
(\mathrm{kN})\end{array}$ & 55 & 30 & 67 & 33 & 33 & 22 & 21 & 13 & 25 & 15 & 23 & 16 \\
\hline \multicolumn{3}{|c|}{ Displacement deviation } & $22 \%$ & $24 \%$ & $-14 \%$ & $20 \%$ & - & - & $21 \%$ & $5 \%$ & $5 \%$ & $40 \%$ \\
\hline \multicolumn{3}{|c|}{ Shear force deviation } & $21 \%$ & $9 \%$ & $-40 \%$ & $-26 \%$ & - & - & $19 \%$ & $12 \%$ & $5 \%$ & $22 \%$ \\
\hline
\end{tabular}


stantially reduces the forces to be resisted at the base and consequently in the earthquake-resistant structural elements, although the displacements do not undergo such significant changes.

The results also show that the foundation is a very influential variable in the responses of a seismic analysis, including the drifts obtained in the comparative analysis.

\section{Special detailing for reinforced concrete structures}

The earthquake-resistant detailing aims at ensuring structural deformability and ductility, since the plastic loading capacity of a structural system, within the scope of the Force Based Design (FBD), is superior to its resistance in the elastic regime. As presented in Fanella [18], the performance of the earthquake-resistant details, specified in the standards, was empirically guided and observed by elements in real situations. In other words, with empirical support, the standards state that the use of the specific patterns of detail suggested ensures that the structure will perform in a more ductile way when subjected to seismic loading, thus allowing for the adoption of more favorable response-modification coefficients. ABNT NBR 15421: 2006 [1] does not clarify in any way what are the criteria adopted for a structure to be considered as specially earthquake-resistant detailed. ASCE / SEI 7 [3] together with $\mathrm{ACl} 318$ [9] and Eurocode 8 [2] present a number of additional considerations that must be followed to ensure adequate seismic performance for the structures. Some of these considerations are presented in what follows.

The elements, whenever possible, should be governed by bending, rather than by shear; the pillars must be stronger than the beams; and the joint regions between elements must have superior resistance to the elements themselves. It is also necessary to consider overloads, load inversion and impact.

The minimum required strength for the concrete is fck $=20 \mathrm{MPa}$, though some standards suggest that, for buildings with more than four floors, a fck $>25 \mathrm{MPa}$ should be adopted; therefore, it should be ideally adopted fck higher than $25 \mathrm{MPa}$ for any structure with special earthquake-resistance reinforcement detail.

For elements designed for pure bending (beams) where normal stress does not exceed $0.1 \mathrm{f}_{\mathrm{ck}}$, the following conditions must be met:

- $b>0.3 \mathrm{D}$, where (b) and (D) are respectively the smallest and largest cross-sectional dimension;

n $b>0.25 \mathrm{~cm}$ (to ensure internal concrete confinement);

- $\mathrm{D}<25 \%$ of span (to avoid wall-beam behavior);

- $b<3 \mathrm{C}_{2}$ or $\mathrm{b}<\mathrm{C}_{2}+1.5 \mathrm{C}_{1}$ (where $\mathrm{C}_{1}$ and $\mathrm{C}_{2}$ are the longitudinal and transversal dimensions of the pillars, respectively);

- $A s, \min =0.25 \frac{\sqrt{f c k}}{f y k} \times b \times D \geq 1.4 \frac{b \times D}{f y k} \quad$ where $\quad \mathrm{b}$ and $\mathrm{D}$ are given in centimeters; $f_{c k}$ and $f_{y k}$ in MPa (for the model building of this study the minimum reinforcement would be approximately twice the one adopted according to NBR 6118);

- Reinforcement ration $<2.5 \%$;

- $\mathrm{A}_{\mathrm{s}, \mathrm{inf}}$ anchored at the bearing $>0.5 \mathrm{~A}_{\mathrm{s}, \mathrm{sup}}$ anchored at the bearing;

- Reinforcement in any region of the beam $\left(A_{s, \min }\right)$ shall not be less than $25 \%$ of the largest portion of required reinforcement $\left(A_{s, \text { maior }}\right)$, according to the expression: $A_{s, \text { min }}>25 \% A_{s, \text { maior }}$.
For transverse reinforcement, the following minimum criteria must be adopted:

Lap splice involved by stirrups of maximum spacing: $\frac{d}{4}$ or 10 $\mathrm{cm}$ (smallest value);

- Longitudinal rebar without a stirrup corner protection at a maximum distance of $15 \mathrm{~cm}$ from a protected rebar;

- Stirrups with $45^{\circ}$ internal hooks and a straight end greater than: $6 \Phi t$ or $8 \mathrm{~cm}$ (the largest value), in which $\Phi t$ is the stirrup diameter;

- In elements where the total normal stress is less than $0.05 \mathrm{f}_{\mathrm{ck}}$ and the portion of the shear stress derived from the seismic load is greater than $50 \%$ of the remainder shear force on the element, the element shall be designed by taking the shear portion absorbed by complementary mechanics to the truss model $\left(V_{c}\right)$ equal to zero;

- The lap splices shall not be placed in regions of probable longitudinal reinforcement yield, that is to say, lap splices shall be avoided in the midspan or in regions as close to pillar intersections as twice the height of the beam, where plastic hinges are more likely to occur.

- The maximum spacing of the stirrups shall be: $\frac{1}{4} D, 6 \Phi_{L}$ or $\left(10+\frac{35-S_{t}}{3}\right)$ (in $\left.\mathrm{cm}\right)$, where $\mathrm{S}_{\mathrm{t}}$ is the transverse spacing of the stirrup section and $\Phi_{L}$ the longitudinal reinforcement diameter; - The stirrups must be closed loops or at most, a "U" shaped stirup with a hat complement, with a $45^{\circ}$ internal hook at every connection;

- The first stirrup shall be at no more than $5 \mathrm{~cm}$ from the face of the support.

For elements designed for compound bending (pillars) where the normal stress is greater than $0.1 \mathrm{fck}$, the following conditions must be met:

a $>0.4 \mathrm{D}$ where (b) and (D) are respectively the smallest and largest cross-sectional dimension;

- $\mathrm{b}>30 \mathrm{~cm}$;

- The sum of the minimum moment applied to a pillar node shall be greater than $6 / 5$ of the sum of the resistant moments of the beams composing the node (if this condition is not satisfied, the stiffness of the element shall be neglected in the seismic analysis);

- Amount of reinforcement adopted so that $1 \%<$ As $<6 \%$;

- Lap splice mandatorily at the element's midspan;

- Minimum stirrups diameters $10 \mathrm{~mm}$;

- Hooks with a straight end greater than $6 \Phi t$ or $8 \mathrm{~cm}$ (the greater value);

- Longitudinal rebar without a stirrup corner protection at a maximum distance of $15 \mathrm{~cm}$ from a protected rebar;

- Every other rebar must be protected by a stirrup corner;

- The cross sectional spacing of the stirrup shall be inferior to $35 \mathrm{~cm}$;

- Reinforcement cover inferior to $10 \mathrm{~cm}$ (when this criterion cannot be met, additional stirrups with no more than $30 \mathrm{~cm}$ spacing distance must be placed for cover protection);

- The pillar anchoring reinforcement must be integrally protected by the transversal reinforcement;

- Shear design considering $\mathrm{V}_{\mathrm{c}}=0$ at regions with the following distances from the support:

$2 \times$ greatest transversal dimension;

$\frac{1}{6}$ span;

or $45 \mathrm{~cm}$. 
The maximum spacing of the stirrups shall be: $\frac{1}{4} D, 6 \Phi \mathrm{L}$ or $\left(10+\frac{35-S_{t}}{3}\right)$ (incm), wheres_tisthetransversespacing of the stirrup section.

For corner joints:

- Admit yield stress $=1.25 \mathrm{f}_{\mathrm{yk}}$ (to ensure that the reinforcement will yield and form a plastic hinge);

- The anchoring must be extended to the end face of the column;

- Good adhesion anchorage $=2 \times l d h$, bad adhesion anchorage $=3.5 \times \mathrm{ld} h$; where $/ d h$ is the anchoring length required for a hooked bar;

- Anchorage outside the containment should be multiplied by a factor of 1.6;

- For beams that end in columns, column dimension $>20 \Phi_{L}$ of beam;

- Pillar's transverse reinforcement must be placed across the entire node;

- Additionally, when the beam section is greater than the pillar's, the beam's transversal reinforcement must be placed across the entire node as well;

- Node shear stress must be inferior to $(\mathrm{kN})$ :

for nodes confined in all directions: $1.7 \sqrt{f c k} \times A j$;

for nodes with a single open end: $1.2 \sqrt{f c k} \times A j$;

for other cases: $1.0 \sqrt{f c k} \times A j$.

where $f_{c k}$ is given in MPa and $A j$ (in squared meter) determined by Figure 5.

An example of conventional detailing in comparison with a special earthquake-resistant detail suggested by the American standard can be seen in Figure 6. For the example, it was considered in a simplified way, the design of one of the beams of the model building presented in the study, with the following loads: self-weight; seismic loads; $3.5 \mathrm{kN} / \mathrm{m}^{2}$ of permanent loads additionally to the self-weight; $5.0 \mathrm{kN} / \mathrm{m}^{2}$ of accidental overload.

\section{Conclusions}

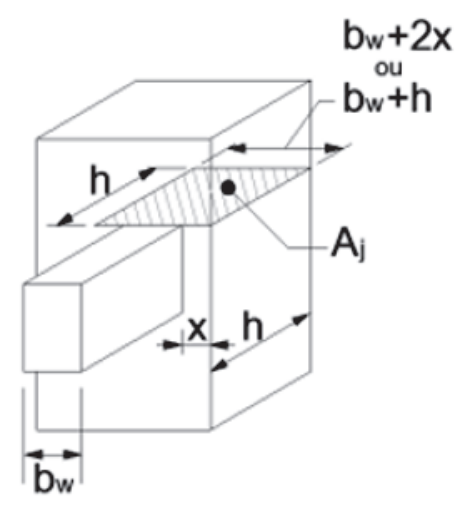

\section{Figure 5}

$A_{j}$ in frame knot

Source: Galvão [10]
1) Although ABNT NBR 15421: 2006 [1] is based on an old American standard - UBC [7], it presents acceptable results for current seismic conditions in Brazil. However, in a globalized world and Brazil being so close to other regions of high seismicity in South America, a more complete standard with updated concepts, like a few discussed within this paper, would be more adequate.

2) The NBR gives a great focus on the implementation of the EFM; however, the application of an improved method (such as the RSM or non-linear analysis) could generate attractively more economical solutions, although the American standard does not allow very significant reductions in relation to the EFM.

3) The use of a specific seismic-resistant detail for regions of high seismicity generates a considerable decrease in the design stresses, through the response-modification coefficients, which can lead to economically more favorable situations, as shown in Table 9 and Table 10, in addition to being a more adequate detailing with respect to the safety and durability of the building. Despite this, NBR does not specify the details that characterize an acceptable earthquake-resistant project, in a way that forces one to seek references in international standards.

4) For the model building analyzed, the compared results were quite different amongst the standards. The parameters used to define the design spectra and consequently the acting forces are quite different, besides the limitations imposed by each standard and the weighting coefficients. Nevertheless, the results have the same order of magnitude and are, therefore, suitable for what they are proposed.

5) Although the RSM does not always produce more favorable results than the EFM, the use of three-dimensional models and more accurate procedures make it possible to precisely capture imperfections and irregularities in the structures, which generally returns more accurate results. New case studies should be studied in order to represent a greater variety of systems and structural arrangements, allowing to better understand the divergences and similarities among the responses of the methods analyzed for each normative instruction.

\section{Acknowledgments}

The second and the third authors express their appreciation to the CNPq, for the research productivity scholarship for the processes 301050/2018-0 and 306355/2017-5 respectively.

\section{Bibliographic references}

[1] ASSOCIAÇÃO BRASILEIRA DE NORMAS TÉCNICAS. ABNT NBR 15421:2006: Projeto de estruturas resistentes a sismos - procedimentos. 1 ed. Rio de Janeiro: 2006.

[2] EUROCODE 8. EN 1998-1: Design of structures for earthquake resistance - General rules, seismic actions and rules for buildings. Commission of the European Community, 2010.

[3] AMERICAN NATIONAL STANDARDS INSTITUTE. ASCE/ SEI 7: Minimum Design Loads for Buildings and Other Structures. 16. Virginia: Structural Engineering Institute, 2016. 

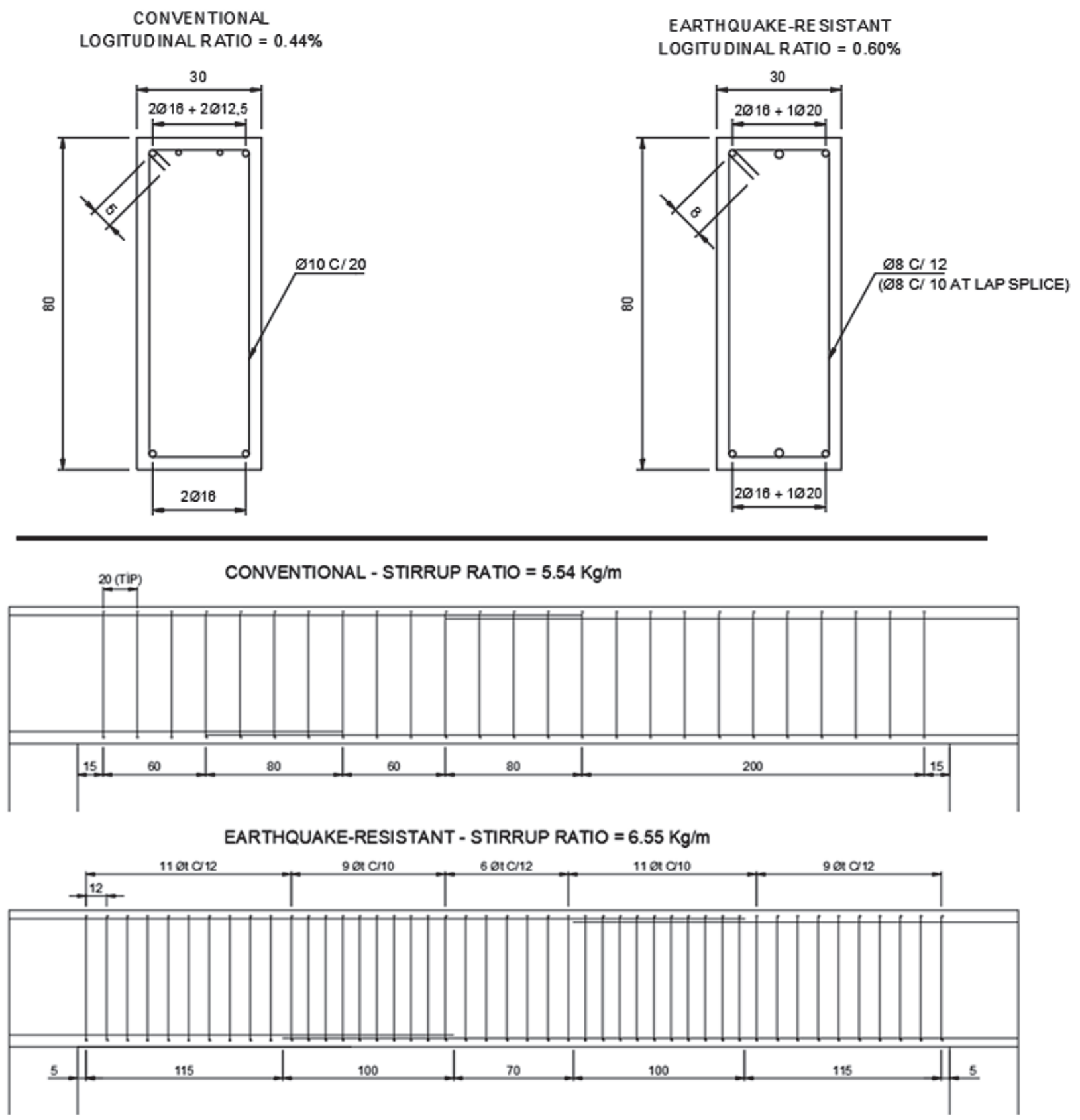

\section{Figure 6}

Comparison between conventional detailing and seismic special detailing

[4] SCIA Engineer, Version 17.0. Nemetschek Group software, 2017. Accessible through: https://www.scia.net

[5] ARAI, Ana. Estudo comparativo de normas de projetos de estruturas resistentes a sismos. 92 f. Dissertação (Mestrado) - Curso de Estruturas, Universidade Federal do Rio de Janeiro, Rio de Janeiro, 2013.

[6] U.S. Seismic Design Maps. USGS, 2018. Accessible through: http://earthquake.usgs.gov/designmaps

[7] INTERNATIONAL CONFERENCE OF BUILDING OFFICIALS. UBC: Volume 2. Whittier, California: 1997.
[8] LIMA, Silvio de Souza; SANTOS, Sergio Hampshire de Carvalho. Análise dinâmica das estruturas. Rio de Janeiro: Ciência Moderna, 2008.

[9] AMERICAN CONCRETE INSTITUTE. ACI 318: Building Code Requirements for Structural Concrete. 11 ed. Farmington Hills, 2011. 503 p.

[10] GALVÃO, Pedro Ivo Ishakewitsch. Definição de requisitos mínimos necessários para o detalhamento sismo-resistente de edifícios em concreto armado no brasil. 2013. 119 f. Dissertação (Mestrado) - Curso de Es- 
truturas, Universidade Federal do Rio de Janeiro, Rio de Janeiro, 2013

[11] PARISENTI, Ronaldo. Estudo de análise dinâmica e métodos da ABNT NBR 15421:2006 para projeto de edifícios submetidos a sismos. 219 f. Dissertação (Mestrado) - Curso de Engenharia Civil, Universidade Federal de Santa Catarina, Florianópolis, 2011.

[12] UNIVERSIDADE DE SÃO PAULO (São Paulo). Secretaria Estadual de Educação. Mapa de risco de tremores de terra no Brasil. Accessible through: < http://jornal.usp.br/tv-usp/ usp-atualiza-mapa-de-risco-de-tremores-de-terra-no-brasil/>. Acesso em: 04 fev. 2018.

[13] FARDIS, Michael N. et al. Seismic Design of Concrete Buildings to Eurocode 8. Londres: Crc Press, 2015.

[14] SANTOS, Sergio Hampshire C.; LIMA, S. S.; ARAI, Ana. Estudo comparativo de normas para o projeto sísmico de estruturas. Revista Ibracon de Estruturas e Materiais, v. 5, n. 6, p.812-819, dez. 2012.

[15] SANTOS, Sergio Hampshire de C. et al. Comparative Study of Codes for Seismic Design of Structures. Mathematical Modelling in Civil Engineering, v. 9, n. 1, p.1-12, 1 mar. 2013.

[16] DHANVIJAY, Vinit; TELANG, Deepa; NAIR, Vikrant. Comparative Study of Different Codes in Seismic Assessment. Comparative Study of Different Codes in Seismic Assessment, v. 2, n. 4, p.1371-1381, jul. 2015.

[17] SANTOS, Sergio Hampshire C. et al. Comparative Study of a Set of Codes for the Seismic Design of Buildings. In: IABSE SYMPOSIUM, 39th., 2017, Vancouver. Engineering the Future. Vancouver, 2017.

[18] FANELLA, David A. Flexural Members of Special Moment Frames. In: FANELLA, David A. Seismic Detailing of Concrete Building. Illinois: Portland Cement Association, 2000. p. 5. 